\title{
The diakonia of the elder according to 1 Peter
}

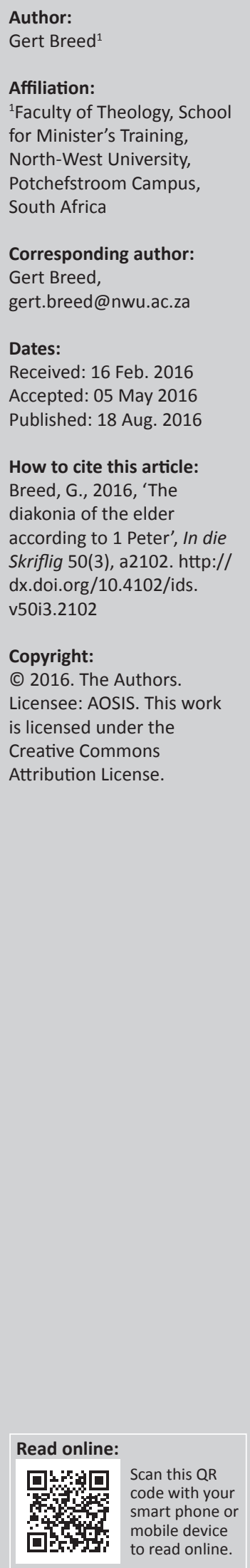

In this article, the ministry of the elder is investigated according to 1 Peter 5:1-5 from the perspective of the usage of the diakon word group in 1 Peter. Firstly, the place of 1 Peter 5 in the context of the whole letter is examined. Then the connection between 1 Peter 5:1-4 and 1 Peter 4:7-11 is ascertained. That is followed by a detailed exegesis of 1 Peter $5: 1-4$. It is found that the immediate context (1 Peter 4), indicates that in 5:1-4, Peter describes the diakonia of the elders. Based on the research, guidelines are suggested for the diakonia of the elder according to 1 Peter.

\section{Introduction}

The aim of this article is to investigate the diakonia ${ }^{1}$ of the elder in the congregation from the perspective of the usage of the diakon word group in 1 Peter. The focus of the research will be on 1 Peter 5:1-4. ${ }^{2} 1$ Peter 5:1-4 will be examined in the context of the whole letter.

\section{Peter}

It is not important for the goal of this article to dwell on the questions of the genre, integrity and literary qualities of the letter. ${ }^{3}$ It is important though to say something about authorship. Jobes (2005:325-337) makes a thorough investigation of the language used in 1 Peter and concludes that Peter could be the author. Love (1954:67) records the similarities between 1 Peter and the speeches of Peter in Acts. The following authors also motivate the conviction that Peter was the author of this letter: Davids (1990:3-7); Grudem (1988:21-33); Marshall (1991:21-24); McKnight (1996:26-29); Michaels (1988:lxvi-lxvii); Miller (1993:57-75); and Schreiner (2003:21-36). These researchers see Peter, the disciple of Jesus, as the author of 1 Peter. The original readers of the letter were congregations consisting of both Jews and non-Jews and were under severe pressure from the people among whom they lived. They had no economic and civil rights because they did not hold citizenship of the places where they lived. Their new Christian life after they had been converted made them the objects of suspicion, contempt and aggression (Achtemeier 2011:76; Fagbemi 2009:2; Joseph 2012:94-121). Kovalishyn (2015) describes the purpose of Peter's letter as follows:

Peter wrote to them to not only encourage and comfort them in their trying situation, but also to urge them on to a special response to the suffering they were experiencing. (p. 234; cf. Breed 2014a:3)

In an analysis of 1 Peter from the perspective of Practical Theology, Breed (2014a:6) finds that the building blocks of Peter's practical theology show that the pastoral character and purpose of the letter binds it together in a unity. Various researchers have confirmed the pastoral character of the letter. McCruden (2007:46) says: 'Much of 1 Peter's characteristic sacrificial appraisal of Jesus, therefore, serves a decidedly pastoral end'. In his discussion of the structure of 1 Peter Feldmeier (2008) states:

The structure intimates that the letter takes up the main themes from various sides in a way that could be described as more counselling/pastoral in order to make its comfort and directives understandable. (p. 22)

Senior and Harrington (2008:12) argue the letter 'employs traditional motifs for pastoral purpose'. It can therefore be assumed that the work of the elder as described in 5:1-4 should also be read in the light of the pastoral character of the letter. 1.This research is done from the viewpoint on the meaning of the daikon word group as represented by die results of Breed ( $2012 ;$
$2013 ; 2014 a ;, 2014 \mathrm{~b})$, Breed and Breed (2010), and Collins (2014). The most basic resolution of this research is that the daikon word
group does not always represent humble service but mostly the work of an envoy. The precise meaning should be determined from
the context.

2.Where no book is indicated, reference is to 1 Peter.

3.J.J. Janse van Rensburg (1992:26-41) and F. Janse van Rensburg (2010; 2011) gives a synopsis of the argument of 1 Peter. In his structural analysis he convincingly motivates the cohesion of the different sections of the letter. For a survey of older and recent literature on 1 Peter, see Joseph (2012:2-25). For an in-depth discussion of the persecution that the readers of Peter suffered, see Williams (2012). For a comprehensive discussion of the genre, authorship, integrity, the situation of the readers, literature and composition of the letter, see Elliott (2000:7-304), Green (2007:1-12), and Jobes (2005:1-58). 


\section{Peter 5:1-4 in the context of the letter}

The importance of 1 Peter 5:1-4 in the letter is indicated by the way Peter addresses the elder. For the first time after the introduction of the letter, Peter strikes a personal note, introducing himself in the manner it is usually done at the beginning of a letter (Vinson, Wilson \& Mills 2010:227). It is the 'most extensive self-description given by the author in this epistle' (Jobes 2005:300). This has given the impression to some commentators that this part of the letter is an add-on from another source, but it can also serve to emphasise what Peter is going to say in these verses. It is therefore important to establish in what way these verses form a unity together with the rest of the letter.

In a detailed analysis of these verses, their connection with the rest of the letter will become clear. However, if the pastoral character of the letter (as indicated above) is taken into consideration, the place of 1 Peter 5:1-4 also becomes clearer. J.J. Janse van Rensburg (1992:29) shows in his synopsis of the argument of 1 Peter that everything said in the letter flows from 1 Peter 1:3-12, which he sums up by saying, 'To God, the Father of our Lord Jesus Christ, all the glory! In His great mercy He gave us new birth'. F. Janse van Rensburg (2010:203) analyses 1 Peter 3:13-17 in detail and shows that the exhortations of 1 Peter 4:1-19 flow from Christ's position of authority as described in 3:13-22. J. Janse van Rensburg (1992:40) does not apply this conclusion to 1 Peter 5:1-7. It can therefore be stated that these verses $(5: 1-7)$ flow from Christ's authority as described in 3:13-22. This can also be said because 1 Peter 5:1-7 speaks of the authority in the church and specifically of the authority of the elder. The proposal of Zwemstra (2003:57) for the structure of 1 Peter 2:13-5:7 shows that $2: 13-3: 12$ indicates '.. the right attitude towards authority in the world' and corresponds to 5:1-7, which indicates 'the right attitude towards authority in the church' (cf. Elliott 1970:371).

Clowney (1988:169-188) suggests a structure of 1 Peter 4:1-11 that emphasises the task of the believers as stewards (oikovó $\mu \mathrm{ol}$; 4:10) of the manifold grace of God. In 5:2 emphasis is laid on the fact that the sheep the elder should shepherd belong to God. The elder should therefore exercise their oversight 'as God would have you'. Although the word oikovó $\mu$ o $\zeta$ is not used here, it is clear that they fulfil the task of stewards over the possessions of God according to his prescriptions (Achtemeier 1996:327).

From the preceding discussion and a study of the narrative in 4:1-5:11 a unity structure can be detected in 4:1-5:11, presented by the diagram in Figure 1 ('Unity structure of 4:1-5:11'; cf. also Achtemeier 1996:321; Green 2007:147, 163-164).

The unity structure of 4:1-5:11 flows forth from Christ's position of authority (3:13-22). From this structure it can be deduced that the main emphasis in $4: 1-5: 11$ is on the holy lives of the believers amidst suffering and temptations. Living a holy life is addressed at the beginning, the end and

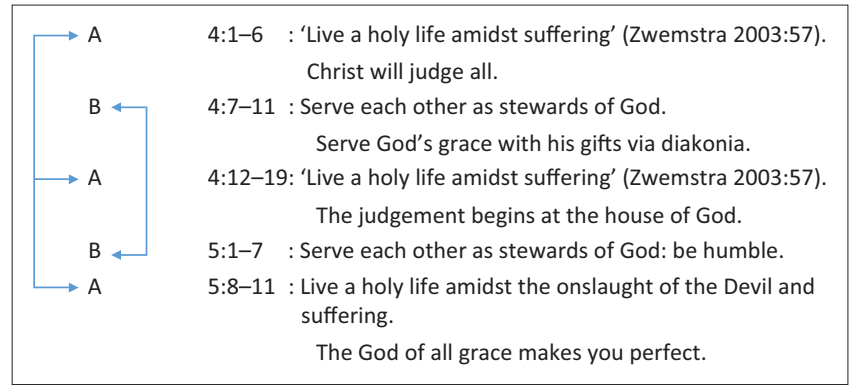

FIGURE 1: Unity structure of 4:1-5:11.

in the middle of the pericope. Service to each other as stewards of God is the way God's grace comes to the believers, and this will help them to persevere amidst suffering and temptations. The close connection between 4:7-11 and 5:1-7 points to the conclusion that 5:1-4 describes the diakonia of the elder. The diakonia of the elder has a pastoral character and they should equip the saints to serve each other with their gifts so that they can live a holy life, no matter how dire their situation.

The pattern that Achtemeier (1996:321) identifies confirms the unity between 4:7-11 and 5:1-4:

A 4:1-6 refers to external relationships; and

B 4:7-11 to internal relationships;

A 4:12-17 again refers to external relationships; and

B 5:1-5 again to internal relationships.

The internal relationships should contribute to the believer's ability to follow Jesus in their external relationships.

From the structure proposed above (Figure 1) and the proposed pattern of Achtemeier (1996:321) 4:1-5:1-5 can be seen as a unity and 5:1-4 should also be understood in the light of 4:1-11. The main emphasis of this pericope is on guiding the congregation to live holy lives through the diakonia of each member and the elder.

If 1 Peter $5: 1-4$ is seen as a description of the service of the elder, it is firstly clear that it is rooted in the authority of Christ; secondly, the service or the ministry of the elder is intended to assist believers to persevere amidst suffering and temptations.

\section{Peter addressing the elder (5:1-2a)}

Peter's address of the elder in 5:1-2a will now be investigated

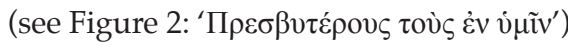

Peter addresses a specific group in the congregation, the

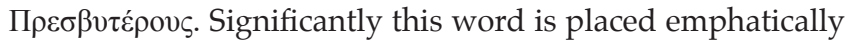
at the beginning of the sentence, but is combined with the

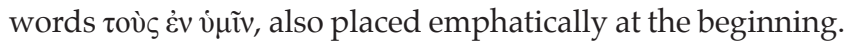
In $5: 2$ the same words are used to describe the members of the congregation ( $\tau$ ò $\dot{\varepsilon} v$ vi $\mu \mathrm{i} v$ roífviov). Peter thus emphasises the unity of the congregation - members and leaders are part of each other. This brings to mind the image that Paul often uses, i.e. the congregation as the body of Christ. In 1 


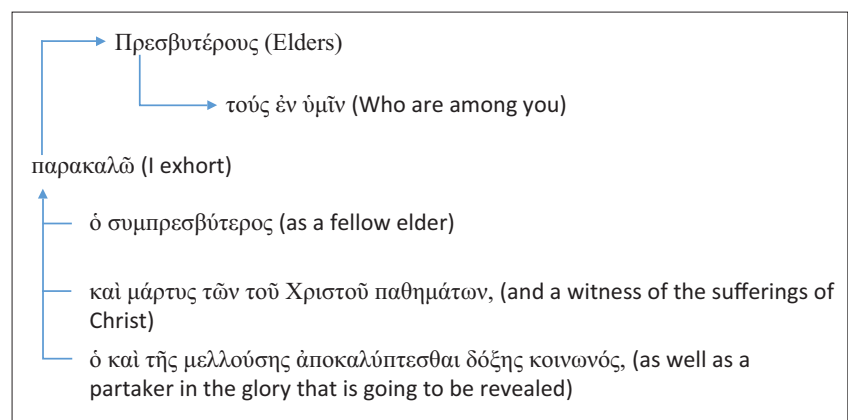

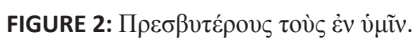

Corinthians 12 Paul emphasises the unity and variety of gifts, the fact that the different members need each other, and the place that the special gifts have in the body (cf. Du Plessis \& Breed 2013:5-6). In Ephesians 4 Paul stresses the unique purpose of the special gifts, i.e. to equip the saints for their diakonia so that everyone can fulfil their function and the body can build itself up in Christ. Peter similarly addresses the elder as part of the congregation. In 1 Peter two metaphors (cf. F. Janse van Rensburg 2005:593-613) express this unity, namely the metaphor of the church as a family with God as the father (1:23), and the metaphor of a building (temple) with Christ as the corner stone (2:4-7). In 4:17 he calls the congregation the household of God; in 1 Peter 4 he emphasises hospitality, love and service towards each other (4:8-11). By repeating the word ' $\dot{\varepsilon} v$ vinv' Peter wants to make certain that the congregation knows that the elder are not a group separate from the congregation, but they are fully part of the congregation.

The word $\pi \rho \varepsilon \sigma \beta v i \tau \varepsilon \rho \varsigma_{,}{ }^{4}$ according to Louw and Nida (1996), occurs in two different domains: 5

- old man: an adult male advanced in years (Lk 1:18; Domain 9.31);

- elder: 'a person with the responsibility and authority with regard to socio-religious matters, in both Jewish and Christian communities', which provides the translational possibility of 'elders' (Ac 20:17; Mt 26:57; Domain 53.77).

Smith (2014) provides the following insight into the meaning of the word 'elder':

The early church adopted the term 'elder' to refer to church leaders. Leadership in the church of Jerusalem consisted of

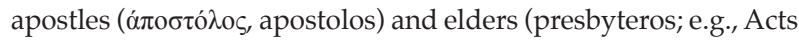
15:2), though the leadership is described only in terms of elders. (presbyteros) in Acts 11:306

In newly planted churches leaders were elected, called and

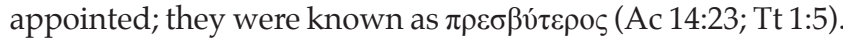
Schreiner (2003) sumarises:

Every piece of evidence we have, shows that elders were widespread in the early church. They are mentioned by different authors: Luke, Paul, Peter, and James. They stretch over a wide

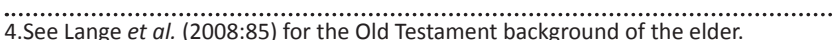
5.Domains (Louw \& Nida 1988) means 'semantic possibilities'.

6.For the history of the use of the term $\pi \rho \varepsilon \sigma \beta \dot{\tau} \tau \varepsilon \rho \rho \varsigma$ and confirmation of its early use in the church, see Jobes (2005:302-304). region of the Greco-Roman world: from Jerusalem, Palestine, the whole of Asia Minor, and Crete. It is also likely that elders functioned as a plurality in the churches since the term is always plural. (p. 231)

In the development of the special services غ̇ंıбкол' eventualy described the same service as $\pi \rho \varepsilon \sigma \beta u ́ \tau \varepsilon \rho \circ$ (see Ac 20:17-35). But in 1 Peter ' $\dot{\pi} \pi \sigma \kappa о \pi \varepsilon \tilde{v}$ had not yet become the technical term regarding a bishop's function, and here elucidates the means by which elder are to shepherd, not a separate task and certainly not a distinct role' (Lynch 2012:535).

According to Louw and Nida (1996), the word, $\pi \alpha \rho \alpha \kappa \alpha \lambda \dot{\varepsilon} \omega$, occurs in four different domains (possibilities) of meaning:

- to ask for something earnestly and with propriety (Ac 28:20) (Domain 33.168);

- to invite (ask somebody to accept offered hospitality - Lk 8:41; 14:8) (Domain 33:315);

- to call together or to call to come to where the speaker is (Ac 28:20) (Domain 33:310); and

- 'To cause somebody to be encouraged or consoled either by verbal or non-verbal means' (Eph 6:22; Phlp 2:1; Domain 25.150).

In the light of the rest of the letter, the first and third of the above possibilities can be applicable. It is not necessary to choose only one possibility. In a certain context a word can carry multiple meanings (Louw \& Nida 1996:408; Domain 33.168). Peter appeals earnestly to the elder to come in their minds to the place where he is in his service to the congregation and in his relationship with Christ. In 5:12 Peter describes the objective of his letter. He uses $\pi \alpha \rho \alpha \kappa \alpha \lambda \varepsilon \dot{\varepsilon} \omega$ together with the word $\dot{\varepsilon} \pi \mu \alpha \rho \tau \nu \rho \varepsilon \dot{\omega} \omega$ to explain what he has done in his letter. According to Louw and Nida (1996) $\dot{\varepsilon} \pi \mu \alpha \rho \tau \nu \rho \dot{\varepsilon} \omega$ occurs in only one domain (possibility) of meaning, namely 'to provide information about a person or an event concerning which the speaker has direct knowledge "to witness"' (Jn 1:7; Lk 21:13) (Domain 33.262). The encouragement that Peter earnestly asks them to accept is something Peter is certain about; in fact, he was an eyewitness. In accord with the purpose of his letter Peter can be characterised as somebody who was certain about his facts when he urged the elder as leaders in the congregation to embrace his encouragement.

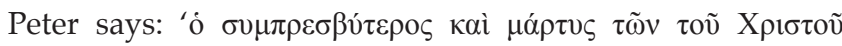

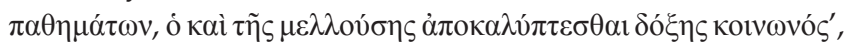
whereby he identifies himself as the one who calls upon the elder. He does it in three ways:

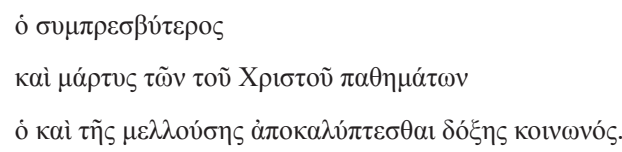

Normally such identification would be found at the beginning of a letter. The fact that it appears at this stage of the letter, shows the importance of what Peter will be saying. It also shows that he needs to establish anew his relationship with the elder and his mandate to say these 
things (Lynch 2012:531). He answers the questions that might arise: 'Who are you to say these things to us?' and 'What is your attitude in saying these things?'

Why does Peter use the word $\sigma 0 \mu \pi \rho \varepsilon \sigma \beta v i \tau \varepsilon \rho \varsigma$ to identify himself? Some researchers say that he wants the elder to know that he does not think himself more important or superior to them and that he associates himself with them (e.g. Jobes 2005:300; Lynch 2012:531). This impression is strengthened by Peter's 'unprecedented shift to first person address and the unmistakable in-house character of his instruction' (Green 2007:162). Peter also makes certain that they remember he is a fellow-elder and therefore has the right to exhort them to fulfil their task. In this way he establishes his authority. The next sentence expands on this notion. Peter

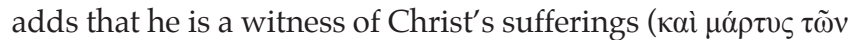

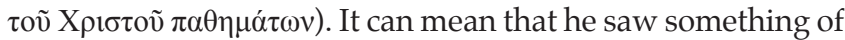
what Jesus suffered through his life and especially at the end of his life, or it can mean that he himself has already suffered for the sake of Christ (Jobes 2005:301, 302). In either way these words bring to mind his previous reference to Christ's suffering, namely in 2:21-25.7 In these verses he asks the congregation to follow in the footsteps of Jesus, who lived in commitment to his calling, and despite his suffering brought healing to the believers. He also compares the congregation to a flock of sheep ( $\pi \rho \circ \operatorname{\beta o\tau } \alpha)$ and calls Jesus the shepherd

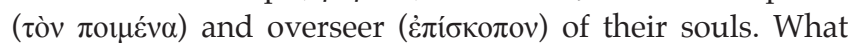
Peter might be saying here is that he has already followed Jesus' example and has experienced suffering for Christ. He therefore has the right to exhort his fellow-elders. He is not asking something from them that he is not ready to suffer himself. This can lead the reader to another conclusion, i.e. that Peter is handing his task of shepherding over to the elder at the end of his epistle. He has been tending the sheep in their dire situation with his letter. He has done it because Jesus called him to do it in John 21:15-17, where he used the same metaphor of sheep and a shepherd. Jesus handed the task of shepherding over to Peter - a task he had received from his Father, and Peter is now handing it over to the elder in their congregation (Achtemeier 1996:322, 324; Elliott 1970:384; 2000:818; Jobes 2005:304).

In the last place Peter identifies himself as 'a partaker in the

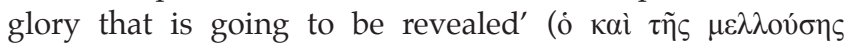

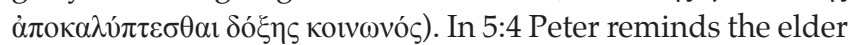
of the promise that when 'the chief Shepherd appears, you

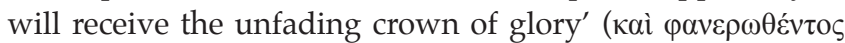

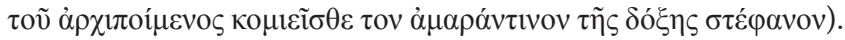
In 1 Peter the relationship between the follower of Jesus' suffering and the glory that is granted or promised is mentioned several times in connection with Christ $(1: 11,21)$ and also in connection with the believers (4:14-16; Feldmeier 2008:233). In the previous instances the glory points to the

7.1 Peter 2:21-25: For to this you have been called, because Christ also suffered for you, leaving you an example, so that you might follow in his steps. He committed no sin, neither was deceit found in his mouth. When he was reviled, he did not revile in return; when he suffered, he did not threaten, but continued entrusting himself to him who judges justly. He himself bore our sins in his body on the tree, that we might die to sin and live to righteousness. By his wounds you have been healed. For you were straying like sheep, but have now returned to the Shepherd and Oversee of your souls. future, and specifically to the second coming of Christ. Schreiner (2003:233) remarks that 'All of the parallels here make it quite certain that the glory promised in 5:1 is the eschatological reward that will be given when Christ returns', and continues by adding: 'Peter encouraged the elders to follow Christ's example, enduring suffering in the present so that they will receive the eschatological reward in the future'.

Ensor (2007:235) says that the meaning of $\delta$ ó $\xi \alpha$ in the New Testament seems to be shaped more by the Hebrew word כָּבוֹד (kābôd, 'glory') and less by secular Greek usage. Kittel, Bromiley and Friedrich (1964, 2:238) state that כָּבוֹ a basic meaning of something 'weighty' in someone, something that gives him or her importance or makes him or her impressive to others.

In 1 Peter the word $\delta$ ó $\xi \alpha$ is used nine times with various applications. Seven of the times $(1: 7,10,20 ; 4: 13 ; 5: 1,4,10)$ references are to the eternal glory that Christ and the believers will receive. Once it refers to the fading glory of the flesh in contrast to the Word of God which remains forever (1:24), and once to the Spirit of glory which rests on believers (4:14). When it refers to eternal glory, it serves as motivation for the believers to persevere in trials and in a holy living. Christ reached the glory through suffering (Green 2007:212), thereby bringing about the salvation of the believers and setting an example for suffering followers. Green (2007) says:

The journey of Christ is proof that suffering on account of one's faithfulness to God is neither the whole nor the end of the story. Rather suffering is a precursor to glory ... the path to vindication and glory is through suffering. (p. 212)

Joseph (2012:105) reasons that Christ's suffering is never discussed in isolation in 1 Peter. He says 'Suffering is followed by resurrection and resurrection followed by glory'. Participation in Jesus' suffering will eventually lead to participation in his glory.

The faithful elder are promised 'the unfading crown of glory' (5:4). The tradition of giving a crown for meritorious work done was widespread in Greco-Roman culture, and 'distinguished statesmen and public benefactors received crowns in recognition of their services, and crowns were also awarded to the victors in both military and athletic events' (Achtemeier 1996:329). This practice was also present in Jewish tradition although in a more limited way. In various New Testament passages (1 Cor 9:25; 2 Tm 4:8; Ja 1:12; Rv $2: 10 ; 3: 11)$ the crown is used as symbol for divineeschatological recognition (Achtemeier 1996:n 125).

In John 12:23-28 the verb, $\delta$ o $\xi \dot{\alpha} \zeta \omega$, plays an important role. Jesus calls his hour of passion and death the hour that the Son of man will be glorified ( $\delta \mathrm{o} \xi \alpha \sigma \theta \tilde{\eta})$. When his soul becomes troubled (Jn 12:27) and he considers if he should ask the Father to save him from the hour, he makes his decision

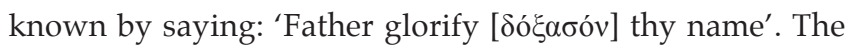

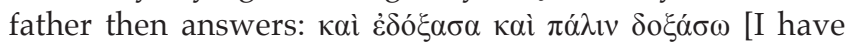
glorified it, and I will glorify it again]. John structures 12:23-28 in such a way to make it clear that Jesus' followers 
are fully involved in this hour (cf. Breed 2014b:3-4). The way that they are involved is through their diakonia, and their diakonia implies that they should be ready to die for Jesus' sake (Jn 12:25-26). ${ }^{8}$ Jesus' promise is that the one who

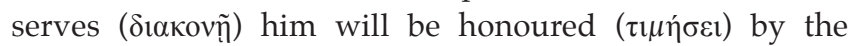
Father. John does not use $\delta$ o $\xi \alpha \dot{\zeta} \omega$ to describe how the Father will honour the diakonos of Jesus, but when John 12:26 is compared to John 17:22, 23, ${ }^{9}$ it becomes clear that the honour includes the glory Jesus gives and the glory flows from being one with Jesus and the Father and with one another. John 12:25-26 speaks of the oneness with Jesus in

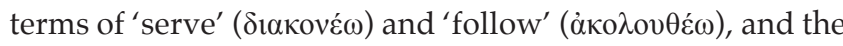
outcome is that he is honoured ( $\tau \mu \eta \dot{\sigma \varepsilon l)}$ by the Father. John 17:22-23 also refers to the oneness, but in terms of the disciples accepting Jesus' words (17:7-8), and the outcome is that they receive the same glory ( $\tau \grave{v} v \delta$ ó $\xi \alpha v$ ) with which Jesus has been glorified.

Honouring, glorifying and diakonia are linked closely together in John as are the elder's faithful fulfilling of their work and their glorification in 1 Peter 5.

This conclusion also corresponds to 1 Peter 4:14: 'If you are insulted for the name of Christ, you are blessed, because the Spirit of glory ( $\left.\delta \delta^{\prime} \xi \alpha\right)$ and of God rests upon you'. As in John 12 and 1 Peter 5:3-4, suffering for Christ and glorification go hand in hand here.

\section{The diakonia of the elder}

Peter describes the diakonia of the elder in 1 Peter 5:2b-3 (see Figure 3 'The task of the elders, 1 Peter 5:2, 3').

The narratological structure of 5:2-3 can be illustrated as follows and is shown in Figure 3 (cf. also Forbes 2014:165).

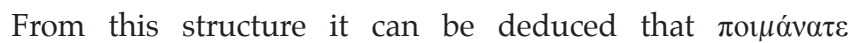
[shepherd] is the main task (diakonia) of the elder, and the way they should fulfil this task is by exercising oversight

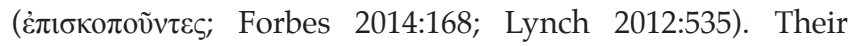
attitude when they exercise oversight is described by the three antitheses in 5:2b-3.

The domains of meaning in which the different words describing the diakonia of the elder can be used, are investigated to establish what their meaning can be in the context of 5:1-4.

\section{$\pi 01 \mu \alpha i ́ v \omega$}

According to Louw and Nida (1996:518, 466, 479), this word occurs in three different domains (possibilities) of meaning:

8.John 12:25-26: Whoever loves his life loses it, and whoever hates his life in this

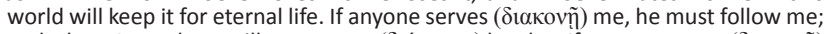

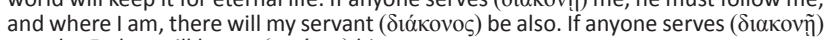
me, the Father will honor ( $(\tau \mu$ í $\sigma \varepsilon 1)$ him.

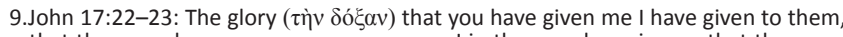
that they may be one even as we are one, I in them and you in me, that they may become perfectly one, so that the world may know that you sent me and loved them even as you loved me.

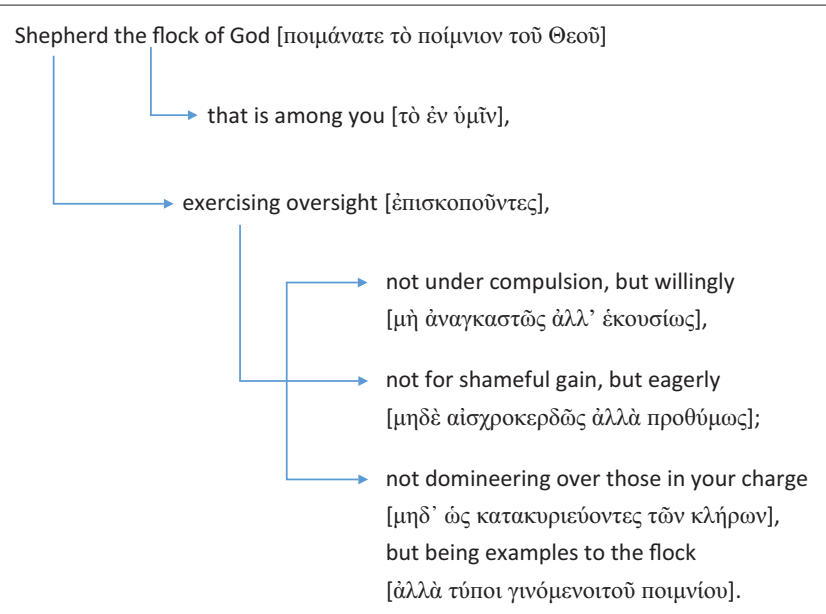

FIGURE 3: The task of the elders, 1 Peter 5:2, 3.

- 'To herd and tend flocks of sheep or goats' (Jh 21:16; Domain 44.3).

- Guide and help or take care of with the implication of providing for (Mt 2:6; Domain 36.2).

- To rule with the implication of direct personal involvementto govern (Rv 2:27; Domain 37.57).

By comparing 1 Peter 5:2 with John 21:15, where John uses the word ßó $\sigma \kappa \omega$ to describe Jesus' command to Peter to care for his lambs, the translation feed is a possibility (cf. also Achtemeier 1996:325; Jobes 2005:304). 1 Peter 5:2 can also be linked with 1 Peter 2:1-5 where Peter calls upon the congregation to build themselves up in their faith by coming to Jesus through the Word so that they can grow in their faith like babies who are fed with milk. Dogterom (2003) points to the ingressive aorist imperative of

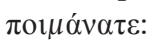

suggesting that energetic action is required. To shepherd is not simply to occupy a position, but to diligently, aggressively, care for the flock placed in one's care. In this care, motive is critical. (pp. 14-16)

Achtemeier (1996:325) says that the image of a shepherd as leader among God's people has a long tradition in Israel as described in the Old Testament (cf. Lynch 2012:530). Boring (2011:170) says for the readers of the eastern Mediterranean the image of shepherd and sheep is not a soft and warm relationship, but one with authority to guide and to rule, like a king should do.

In the context of the whole letter $\pi$ or $\mu$ aiv $\omega$ here caries a strong pastoral content. The elder should shepherd the flock of God in their practical (dire) situation, as Peter does in the letter. They are accountable to God who put the sheep under their care (among them). They conduct their task with the authority of the Chief Shepherd, Christ (cf. 5:4; Lynch 534).

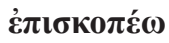

According to Louw and Nida (1996), this word occurs in three different domains: 
- 'To take care of or tend with the implication of continuous responsibility' (Ac 15:14; Domain 35.39).

- 'To give careful consideration to something with the implication of guarding against' (Heb 12:15; Domain 30.46).

- To minister or serve, that is 'to have the responsibility of taking care of someone, with the implication of an official responsibility within a congregation', providing translational possibilities as 'to minister/serve, to take the responsibility, to take care of' (Domain 53.70).

Louw and Nida (1996, at 53.71) make an important remark:

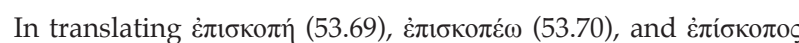
$(53,71)$, it is important to combine the concepts of both service and leadership, in other words, the responsibility of taking care of the needs of the congregation as well as directing the activities of the membership.

F. Janse van Rensburg (2009:426) comments: 'A good translational equivalent could for instance be "helper and leader", or perhaps "guardian"'.

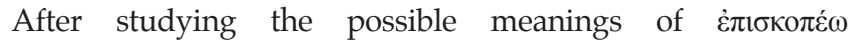
and etymologically related words, F. Janse van Rensburg

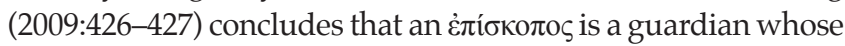
task is leadership that takes place through service; thus someone who has church leadership as ministry. The guardian's task means they have to take care of God's flock like shepherds ( $\pi$ ouóv $\alpha \tau \varepsilon)$, which among others means they must have a gift

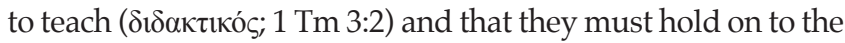
good doctrine so that they can teach it to others and refute

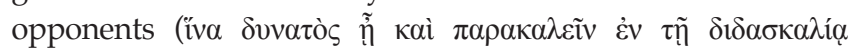

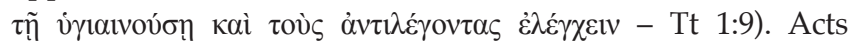
20:28 has the following instruction for the elder:

Pay careful attention to yourselves and to all the flock, in which

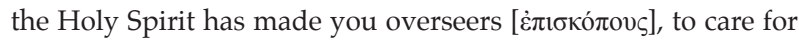
the church of God, which he obtained with his own blood.

Titus 1:7 uses another image, namely that of the guardian

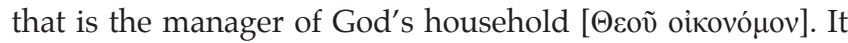
means that while God is the kurios [boss of the house], the $\dot{\varepsilon} \pi \iota \sigma \kappa o ́ \pi$ oi manages the house with a mandate from the house boss (Janse van Rensburg 2009:427). Wilson (2015:1) says that the work of the elder in the New Testament is bound up with the idea of 'serving the church by protecting her from harm'. Zerwick and Grosvenor (1974:714) say that the root of $\dot{\varepsilon} \pi \mathrm{l}-\sigma \kappa о \pi о \tilde{v} v \tau \varepsilon \varsigma$ is $\sigma \kappa о \pi \dot{\varepsilon} \omega$ [oversee] and that $\dot{\varepsilon} \pi \mathrm{l}-\sigma \kappa о \pi о \tilde{v} \tau \varepsilon \varsigma$ "combines the senses of "superintend" and "watch over", authority and care'.

The way the elder should shepherd the flock is thus by watching over them with diligence, using their authority to protect the sheep from harm.

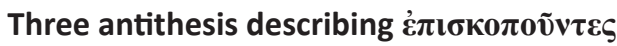

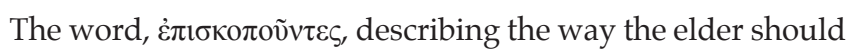

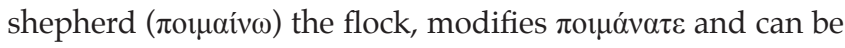
seen as an adverbial participle (Achtemeier 1996:325; Vinson et al. 2010:231, 232), and it 'is then further modified by three sets of adverbial qualifiers' (Jobes 2005:304). The meaning of these qualifiers are as follows:

The first antithesis (qualifier):

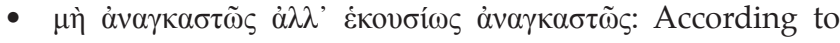
Louw and Nida (1996:671) this word occurs in only one domain (possibility) of meaning: 'To be obligatory on the basis of being imposed' (1 Pt 5:2; Domain 71.31). Peter tells them that their motivations for shepherding and overseeing should not come from outside themselves. The elder should be self-motivated in their diakonia.

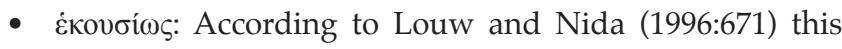
word occurs in only one domain (possibility) of meaning: 'to be willing to do something without being forced or pressured - willingly of one's own free will'. (Phlm 14; Domain 25.65).

For the congregation it means that they should never put pressure on somebody to become an elder. 1 Timothy 3:1 states the positive side of this antithesis as mentioned by Liddell et al. (1996):

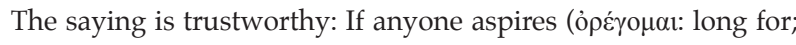

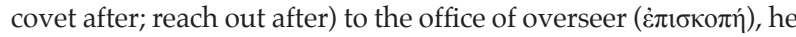

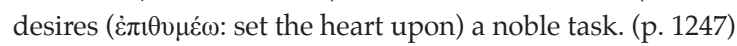

Both 1 Peter 5 and 1 Timothy 3 speaks of somebody who has an active longing to do the work of an overseer.

The second antithesis (qualifier):

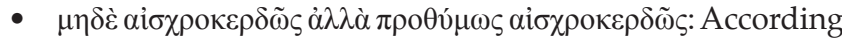
to Louw and Nida (1996:292), this word occurs in only one domain (possibility) of meaning: 'To be shamefully greedy for material gain or profit'. (1Tt 3:8; Domain 25.26)

- $\pi \rho \circ \theta \dot{\mu} \omega \varsigma$ : According to Louw and Nida (1996:671), also this word occurs in only one domain (possibility) of meaning: to be eager to do something. They (1996:297) suggest translating 1 Peter 5:2 as follows: 'Look after it ... not for pay, but from a real eagerness to serve'. They are of the opinion that it would be wrong to equate the

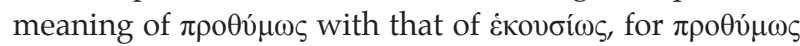

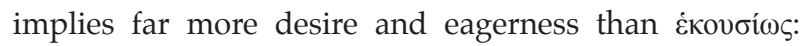
'They are not to do so under compulsion ( $\dot{\alpha} v \alpha \gamma \kappa \alpha \sigma \tau \tilde{\omega} \varsigma)$ but

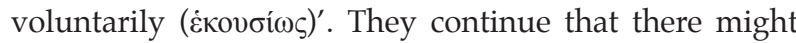
have been some elder who did not wish to serve and were exercising oversight unwillingly. Peter wanted a shift in attitude from them. Vincent (1987:666) contends that 'willingly' is not a strong enough translation of $\pi \rho 0 \theta v \mu \omega \varsigma_{\text {, }}$ saying the latter denotes 'a forward spirit; ... not mere willingness, but zeal'.

The question in this antithesis is what the source of motivation is for the elder. If money motivates you to be an elder, it is wrong. The motivations should come from your relationship with God and his flock (5:4, 6).

The third antthesis (qualifier): 


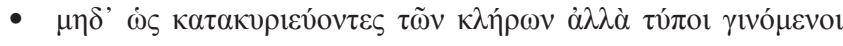

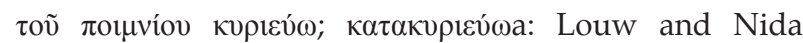
(1996:37.50) suggest the following possible meaning of the word: to rule or reign over, with the implication in some contexts of 'lording it over' - 'to rule, to govern, to reign over'.

Thayer (1889) gives the following possible meanings of the word:

To bring under one's power, to subject to one's self, to subdue, master: $\tau \imath v o ́ s$, Ac 19:16 and to hold in subjection, to be master of,

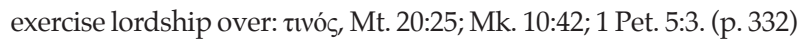

Thayer's interpretation seems to fit the given Scriptural passages best.

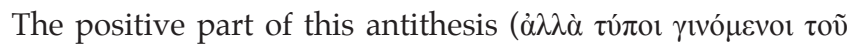
$\pi$ ouvíov ${ }^{*}$ describe the attitude of the eldes as people who could be followed in their example of service to the flock: 'Followers of Jesus are to use their authority to serve, and in that way they imitate the example of Jesus himself (Matt 20:28; Mark 10:45)' (Schreiner 2003:235).

All of these antitheses speak about the motivation to do the work as an overseer. The first antithesis says that the motivation should not flow from the outside pressure of other people, but the motivation should come from inside the elder. The second antithesis says that money should not motivate the elder, but an eagerness to serve the flock. The last antithesis says that power over other people should not be the motivation, but the desire to be an example to the flock of somebody who follow Jesus' example.

\section{Translation of 1 Peter 5:2-3}

1 Peter 5:2-3 can now be interpreted as follows in the context of the letter: Elder, you who are under the authority of Christ, use your authority to care diligently, aggressively for the flock placed in your care:

- overseeing them not as if it is a task imposed on you ( $\mu$ ì $\dot{\alpha} v \alpha \gamma \kappa \alpha \sigma \tau \tilde{\omega} \varsigma)$, but willingly without outside pressure ( $\dot{\alpha} \lambda \lambda$ '

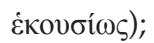

- overseeing them not for pay ( $\mu \eta \delta \dot{\varepsilon} \alpha i َ \sigma \chi \rho \circ \kappa \varepsilon \rho \delta \tilde{c} \varsigma)$, but from a real eagerness to serve; and

- not subjecting them to you, but living as an example of service as Christ has; and

- thereby protecting them from any harm.

\section{Conclusion}

1 Peter 5:1-5 can be seen as part of a well-structured letter and its place within the letter contributes to the way the ministry of the elder should be understood.

There is a close connection between 1 Peter 4 and 5, which points to the conclusion that 5:1-5 describes the diakonia of the elder. From the place of 1 Peter 5:1-5 in the structure of the letter the following can be deduced:
- The diakonia of the elder is rooted in the authority of Christ.

- The diakonia of the elder is a pastoral task.

- The elder should take over the pastoral care that Peter with his letter has given to the congregation in their practical situation.

Peter describes the diakonia of the elder with the words

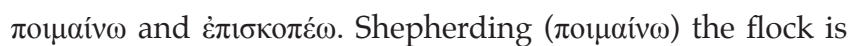
the main content of the elder's diakonia. The way the shepherding should be done is described by the word $\dot{\varepsilon} \pi \iota \kappa \pi_{\varepsilon} \omega$ [oversee]. Oversee in this context also mean to protect the sheep from harm. The attitude (motivation) with which the elder should carry out the overseeing is described in three antitheses, and this attitude points to the attitude of Christ.

\section{Acknowledgements Competing interests}

The author declares that he has no financial or personal relationships which may have inappropriately influenced him in writing this article.

\section{References}

Achtemeier, P.J., 1996, 1 Peter: A commentary on first Peter, Fortress, Augsburg.

Achtemeier, P.J., 2011, '1 Peter 4:1-8', Interpretation 65(1), 76-78. http://dx.doi. org/10.1177/002096431106500109

Boring, M.E., 2011, Abingdon New Testament Commentaries: 1 Peter, Abingdon, Nashville, TN.

Breed, G., 2012, 'Nuut gedink oor die wese en inhoud van die dienswerk van die diaken', HTS Teologiese Studies/Theological Studies 68(1), 1-8. http://dx.doi. org/10.4102/hts.v68i1.1059

Breed, G., 2013, 'Metateoretiese vertrekpunte ten opsigte van wetenskaplike navorsing in gemeentebediening', In die Skriflig/In Luce Verbi 47(1), Art. \#88, 10 pages. http://dx.doi.org/10.4102.ids.v47i1.88

Breed, G., 2014a, 'The diakonia of practical theology to the alienated in South Africa in the light of 1 Peter', Verbum et Ecclesia 35(1) Art., \#847, 9 pages. http://dx.doi. org/10.4102/ve.v35i1.847

Breed, G., 2014b, 'The meaning of the diakon word group in John 12:26 applied to the ministry in congregations', Verbum et Ecclesia 35(1), Art. \#844, 8 pages. http:// dx.doi.org/10.4102/ve.v35i1.844

Breed, G. \& Breed, D.G., 2010, 'Besinning oor die diakonale dienswerk na aanleiding van Handelinge 6:1-7', In die Skriflig 44(3/4), 627-653. http://dx.doi.org/10.4102/ ids.v44i3/4.165

Clowney, E., 1988, The message of 1 Peter: The way of the cross, InterVarsity, Downers Grove, IL.

Collins, J.N., 2014, Diakonia studies: Critical issues in ministry, Oxford University Press, New York.

Davids, P.H., 1990, The first epistle of Peter, Eerdmans, Grand Rapids, MI. (New International Commentary on the New Testament).

Dogterom, W.H., 2003, A rationale and strategy for the spiritual formation of pastoral students, D.Min. dissertation, School of Theology, Fuller Theological Seminary, Ann Arbor, MI.

Du Plessis, A.L. \& Breed, G., 2013, 'A possible solution for corruption in South Africa with the church as initiator: A practical theological approach', HTS Teologiese Studies/Theological Studies 69(2), Art. \#1298, 10 pages. http://dx.doi. org/10.4102/hts.v69i2.1298

Elliott, J.H., 1970, 'Ministry and church order in the NT: A traditio-historical analysis (1 Pt 5:1-5 and parallels)', The Catholic Biblical Quarterly 32(3), 367-391.

Elliott, J.H., 2000, 1 Peter: A new translation with introduction and commentary, Doubleday, New York.

Ensor, P., 2007, 'The glorification of the son of man: An analysis of John 13:31-32', Tyndale Bulletin 58(2), 229-252.

Fagbemi, S.A.A., 2009, 'Living for Christ in a hostile world: The Christian identity and its present challenges in 1 Peter', Transformation: An International Journal of HolisticMissionStudies26(1),1-14.http://dx.doi.org/10.1177/0265378809102172

Feldmeier, R., 2008, The first letter of Peter: A commentary on the Greek text, Baylor University Press, Waco, TX.

Forbes, G., 2014, 1 Peter, B \& H, Nashville, TN. 
Green, J.B., 2007, 1 Peter, Eerdmans, Grand Rapids, Ml. (The two horizons New Testament commentary)

Grudem, W., 1988, The first epistle of Peter: An introduction and commentary, Eerdmans, Grand Rapids, MI. (Tyndale New Testament Commentaries, 17).

Janse van Rensburg, F., 2010, 'Die eskatologie van 1 Petrus: Hoop en vindikasie vir tydelike en permanente uitlanders', In die Skriflig 44(1), 201-228. http://dx.doi. org/10.4102/ids.v44i1.144

Janse van Rensburg, F., 2011, 'Constructing the economic-historic context of 1 Peter: Exploring a methodology', HTS Teologiese Studies/Theological Studies 67(1), 1-11. http://dx.doi.org/10.4102/hts.v67i1.939

Janse van Rensburg, F.J., 2005, 'Die identifisering van soteriologiese metafore in 1 Petrus', In die Skriflig 39(3), 593-613. http://dx.doi.org/10.4102/ids.v39i3.404

Janse van Rensburg, F.J., 2009, 'Studie 1: Bibliologiese studie oor die ouderling in die NT kerk', in Handelinge van die eerste algemene sinode van die Gereformeerde Kerke in Suid-Afrika gehou te Potchefstroom op 5 Januarie 2009 en volgende dae asook 29 Junie 2009 en volgende dae, pp. 425-434. GKSA, Potchefstroom.

Janse van Rensburg, J.J., 1992, 'The outline of 1 Peter: A reconsideration', Ekklesiastikos Pharos 74(1), 26-41.

Jobes, K., 2005, 1 Peter: Baker exegetical commentary on the New Testament, Baker Academic, Grand Rapids, MI.

Joseph, A.P., 2012, A narratological reading of 1 Peter, Clark, New York. (Library o New Testament studies 440).

Kittel, G., Bromiley, G.W. \& Friedrich, G. (eds.), 1964, Theological dictionary of the New Testament (electronic edn.), Eerdmans, Grand Rapids, MI.

Kovalishyn, M.K., 2015, 'Endurance unto salvation: The witness of first Peter and James', Word \& World 35(3), 231-240.

Lange, J.P., Schaff, P., Fronmüller, G.F.C. \& Mombert, J.I., 2008, A commentary on the Holy Scriptures: 1 Peter, Logos Bible Software, Bellingham, WA.

Liddell, H.G., Scott, R., Jones, H.S. \& McKenzie, R., 1996, A Greek-English lexicon, Clarendon, Oxford.

Louw, J.P. \& Nida, E.A., 1988, Greek-English lexicon of the New Testament, based on semantic domains, 2 vols., UBS, New York.

Louw, J.P. \& Nida, E.A., 1996, Greek-English lexicon of the New Testament: Based on semantic domains (electronic edn. of the 2 nd edn.), United Bible Societies, New York.
Love, J.P., 1954, 'First epistle of Peter', Interpretation 8(1), 63-87. http://dx.doi. org/10.1177/002096435400800107

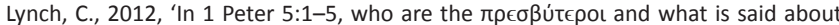
their role?', Expository Times 123(11), 529-540. http://dx.doi.org/10.1177/ 0014524612448736

Marshall, I.H., 1991, 1 Peter, InterVarsity, Downers Grove, IL. (IVP New Testament Commentary)

McCruden, K.B., 2007, 'Compassionate soteriology in Hebrews, 1 Peter, and the Gospel of Mark', Biblical Research 52, 41-56.

McKnight, S., 1996, 1 Peter, Zondervan, Grand Rapids, MI. (NIV Application Commentary).

Michaels, J.R., 1988, Peter, Word Books, Waco, TX. (World Biblical Commentary, 49).

Miller, D.G., 1993, On this rock: A commentary on first Peter, Pickwick, Allison Park, PA. (Princeton Theological Monograph Series, 34).

Schreiner, T.R., 2003, 1, 2 Peter, Jude, Broadman \& Holman, Nashville, TN. (New American Commentary, 37).

Senior, D. \& Harrington, D.J., 2008, 1 Peter, Jude and 2 Peter, Liturgical Press, Collegeville, PA.

Smith, C.A., 2014, 'Church leadership', in D. Mangum, D.R. Brown, R. Klippenstein \& R. Hurst (eds.), Lexham theological wordbook, Lexham Press, Bellingham, WA.

Thayer, J.H., 1889, A Greek-English lexicon of the New Testament: Being Grimm's Wilke's Clavis Novi Testamenti, Harper, New York.

Vincent, M.R., 1987, Word studies in the New Testament, Scribner, New York.

Vinson, R.B., Wilson, R.F. \& Mills, W.E., 2010, 1 \& 2 Peter, Jude, Smyth \& Helwys, Magon.

Williams, T.B., 2012, Persecution in 1 Peter: Differentiating and contextualizing early Christian suffering, Brill, Boston, MA.

Wilson, A., 2015, 'Brothers, we are not managers: We have forgotten the Bible's rich language for loving the church', Christianity Today 59(5), 1-30.

Zerwick, M. \& Grosvenor, M., 1974, A grammatical analysis of the Greek New Testament, Biblical Institute Press, Rome.

Zwemstra, J., 2003, 'Die kommunikatiewe funksies van die spore van Psalms in 1 Petrus', MA-verhandeling, Fakulteit Teologie, Noordwes Universiteit, Potchefstroom. 